\title{
Methanoregula formicica sp. nov., a methane- producing archaeon isolated from methanogenic sludge
}

\section{Correspondence \\ Hiroyuki Imachi imachi@jamstec.go.jp}

\author{
Yuto Yashiro, ${ }^{1,2}$ Sanae Sakai, ${ }^{1}$ Masayuki Ehara, ${ }^{1,2}$ Masayuki Miyazaki, ${ }^{1}$ \\ Takashi Yamaguchi $^{2}$ and Hiroyuki Imachi ${ }^{1}$
${ }^{1}$ Subsurface Geobiology Advanced Research (SUGAR) Team, Extremobiosphere Research Program, Institute of Biogeosciences, Japan Agency for Marine-Earth Science \& Technology (JAMSTEC), Yokosuka, Kanagawa 237-0061, Japan

${ }^{2}$ Department of Environmental Systems Engineering, Nagaoka University of Technology, Nagaoka, Niigata 940-2188, Japan

\begin{abstract}
A novel methane-producing archaeon, strain $\mathrm{SMSP}^{\top}$, was isolated from an anaerobic, propionatedegrading enrichment culture that was originally obtained from granular sludge in a mesophilic upflow anaerobic sludge blanket (UASB) reactor used to treat a beer brewery effluent. Cells were non-motile, blunt-ended, straight rods, 1.0-2.6 $\mu \mathrm{m}$ long by $0.5 \mu \mathrm{m}$ wide; cells were sometimes up to $7 \mu \mathrm{m}$ long. Asymmetrical cell division was observed in rod-shaped cells. Coccoid cells (0.5-1.0 $\mu \mathrm{m}$ in diameter) were also observed in mid- to late-exponential phase cultures. Growth was observed between 10 and $40{ }^{\circ} \mathrm{C}$ (optimum, 30-33 ${ }^{\circ} \mathrm{C}$ ) and $\mathrm{pH} 7.0$ and 7.6 (optimum, $\mathrm{pH}$ 7.4). The $\mathrm{G}+\mathrm{C}$ content of the genomic DNA was $56.2 \mathrm{~mol} \%$. The strain utilized formate and hydrogen for growth and methane production. Based on comparative sequence analyses of the 16S rRNA and $m c r A$ (encoding the alpha subunit of methyl-coenzyme M reductase, a key enzyme in the methane-producing pathway) genes, strain $\mathrm{SMSP}^{\top}$ was affiliated with group $\mathrm{E} 1 / \mathrm{E} 2$ within the order Methanomicrobiales. The closest relative based on both 16S rRNA and mcrA gene sequences was Methanoregula boonei $6 \mathrm{~A}^{\top}$ (96.3\% 16S rRNA gene sequence similarity, $85.4 \%$ deduced McrA amino acid sequence similarity). The percentage of 16S rRNA gene sequence similarity indicates that strain $\mathrm{SMSP}^{\top}$ and Methanoregula boonei $6 \mathrm{~A}^{\top}$ represent different species within the same genus. This is supported by our findings of shared phenotypic properties, including cell morphology and growth temperature range, and phenotypic differences in substrate usage and $\mathrm{pH}$ range. Based on these genetic and phenotypic properties, we propose that strain $\mathrm{SMSP}^{\top}$ represents a novel species of the genus Methanoregula, for which we propose the name Methanoregula formicica sp. nov., with the type strain $\mathrm{SMSP}^{\top}\left(=\mathrm{NBRC}_{105244^{\top}}\right.$ $=$ DSM 22288 ${ }^{\top}$ ).
\end{abstract}

The group E1/E2, originally called the R10 group or fen cluster, is a family-level clade within the order Methanomicrobiales, which comprises $\mathrm{H}_{2} / \mathrm{CO}_{2}$-using methanogenic archaea (Hales et al., 1996; Bräuer et al., 2006b; Galand et al., 2002; Cadillo-Quiroz et al., 2006). This clade has long been recognized as an uncultured

\footnotetext{
Abbreviations: FISH, fluorescence in situ hybridization; UASB, upflow anaerobic sludge blanket.

The GenBank/EMBL/DDBJ accession numbers for the 165 rRNA and mcrA gene sequences of strain $\mathrm{SMSP}^{\top}$ are AB479390 and AB479391, respectively. Other $16 \mathrm{~S}$ rRNA gene clone sequences have been deposited under accession numbers AB479392-AB479411.

A supplementary figure and two supplementary tables are available with the online version of this paper.
}

group; however, to date, three methanogenic strains have been isolated and characterized: Methanoregula boonei $6 \mathrm{~A} 8^{\mathrm{T}}$ (Bräuer et al., 2006a, 2011), Methanosphaerula palustris E1-9c ${ }^{\mathrm{T}}$ (Cadillo-Quiroz et al., 2008, 2009) and Methanolinea tarda NOBI- $1^{\mathrm{T}}$ (Imachi et al., 2008). Methanoregula boonei and Methanosphaerula palustris were isolated from peatlands, while Methanolinea tarda was isolated from a methanogenic digester. In addition to the these isolates, many $16 \mathrm{~S}$ rRNA gene clones belonging to group E1/E2 have been retrieved from a wide variety of anoxic environments, such as bogs and fens (Bräuer et al., 2006a, b; Cadillo-Quiroz et al., 2006, 2008; Chan et al., 2002; Galand et al., 2002), methanogenic sludges (Imachi et al., 2008; Chen et al., 2004, 2009; Narihiro et al., 2009), contaminated aquifers/groundwaters (Dojka et al., 1998; 
Ficker et al., 1999; Watanabe et al., 2002; Macbeth et al., 2004), rice-field soils (Großkopf et al., 1998; Lueders \& Friedrich, 2000; Wu et al., 2006), freshwater sediments (Jurgens et al., 2000; Nüsslein et al., 2001; Chan et al., 2005) and brackish sediment (Purdy et al., 2002) and as endosymbionts of anaerobic ciliates (van Hoek et al., 2000) (see Supplementary Fig. S1, available in IJSEM Online), indicating the widespread distribution of E1/E2 methanogens.

Recently, we successfully isolated a novel methanogenic archaeon, strain $\mathrm{SMSP}^{\mathrm{T}}$, belonging to group E1/E2, from methanogenic granular sludge in an upflow anaerobic sludge blanket (UASB) reactor. In this report, we describe the detailed morphological and physiological characteristics and genetic features of strain SMSP ${ }^{\mathrm{T}}$. Because the genetic and phenotypic properties of strain $\mathrm{SMSP}^{\mathrm{T}}$ are generally similar to those of Methanoregula boonei, described elsewhere in this issue (Bräuer et al., 2011), we propose that this strain represents a second species of the genus Methanoregula.

Methanogenic granular sludge was taken from a full-scale mesophilic $\left(30-35{ }^{\circ} \mathrm{C}\right)$ UASB reactor located in Japan that was treating beer brewery wastewater. The granules were yellowish brown to dark brown and about $2-3 \mathrm{~mm}$ in diameter. After sampling, the granular sludge was washed immediately with phosphate buffer (10 mM, pH 7.2) under $\mathrm{N}_{2}$ and then homogenized briefly before inoculation into primary enrichment culture medium. The medium for cultivation of strain $\mathrm{SMSP}^{\mathrm{T}}$ was prepared as described previously (Imachi et al., 2009). Enrichment cultures were incubated anaerobically at $37{ }^{\circ} \mathrm{C}$ in $50 \mathrm{ml}$ serum vials containing $20 \mathrm{ml}$ medium $\left(\mathrm{pH}\right.$ at $\left.25^{\circ} \mathrm{C}, 7.0\right)$ under an atmosphere of $\mathrm{N}_{2} / \mathrm{CO}_{2}(80: 20, \mathrm{v} / \mathrm{v})$ without shaking, unless indicated otherwise. After isolation of the strain, all incubations were performed at $33{ }^{\circ} \mathrm{C}$. Growth and substrate utilization were determined by monitoring the $\mathrm{OD}_{400}$ of the culture and methane production in basal medium containing $0.01 \%(\mathrm{w} / \mathrm{v})$ yeast extract, $1 \mathrm{mM}$ acetate and $0.5 \mathrm{mM}$ coenzyme $\mathrm{M}$ (2-mercaptoethanesulfonic acid). Effects of $\mathrm{pH}$, temperature, $\mathrm{NaCl}$ concentration and antibiotics on growth of strain $\mathrm{SMSP}^{\mathrm{T}}$ were determined in basal medium containing $40 \mathrm{mM}$ formate plus $0.01 \%(\mathrm{w} / \mathrm{v})$ yeast extract, $1 \mathrm{mM}$ acetate and $0.5 \mathrm{mM}$ coenzyme $\mathrm{M}$ in triplicate culture vessels. All incubations for these tests were performed for over 2 months. To evaluate the optimum temperature for growth, the strain was cultivated at $4,10,15,20,25,30,33,37,40,45,50$ and $60{ }^{\circ} \mathrm{C}$. To determine the $\mathrm{pH}$ range for growth, the medium was adjusted at room temperature to $\mathrm{pH} 5.0-8.5$ by adding $\mathrm{HCl}$ or $\mathrm{NaOH}$ solution under a $100 \% \mathrm{~N}_{2}$ atmosphere prior to inoculation. The $\mathrm{pH}$ of the medium was monitored every 4 days during growth using a portable $\mathrm{pH}$ meter (Horiba Twin $\mathrm{pH} \mathrm{B-212),} \mathrm{and} \mathrm{the} \mathrm{pH}$ was readjusted by using $\mathrm{HCl}$ or $\mathrm{NaOH}$ if the initial $\mathrm{pH}$ had changed significantly. The $\mathrm{pH}$ test was performed twice. To test the effect of $\mathrm{NaCl}$ concentration on growth, $\mathrm{NaCl}$ was added to the medium at final concentrations of $1-30 \mathrm{~g}^{-1}$.
Antibiotic susceptibility was examined with cultures supplemented with antibiotics at final concentrations of $100 \mu \mathrm{g} \mathrm{ml}^{-1}$.

Cell morphology was examined under an epifluorescent microscope (Olympus BX51F) with a colour CCD camera system (Olympus DP71). Susceptibility to lysis was examined by adding SDS to final concentrations of $0.01-$ $1.0 \%(\mathrm{w} / \mathrm{v})$, and cell lysis was determined by microscopic observation. The G+C content of the genomic DNA was determined by HPLC, as described previously (Nakagawa et al., 2003). Procedures for DNA extraction and PCR amplification were reported previously (Imachi et al., 2006). In the PCR amplification, we used the primer pair Ar109f (Großkopf et al., 1998) and 1490R (Weisburg et al., 1991) for construction of 16S rRNA gene-based archaeal clone libraries. We also used primer pairs Arch21F (DeLong, 1992)/1490R and ME1/ME2 (Hales et al., 1996) for amplification of the 16S rRNA gene and morA gene of the isolate, respectively. PCR products were purified with a MinElute PCR purification kit (Qiagen) and subsequently cloned into Escherichia coli TOP10 using a TOPO TA cloning kit (Invitrogen). Sequences of the 16S rRNA genes of clones and the pure culture were determined with a Big Dye terminator version 3.1 cycle sequencing kit (Applied Biosystems) and an automated sequence analyser (3130xl Genetic Analyzer; Applied Biosystems). Phylogenetic analyses were performed as described previously (Imachi et al., 2006, 2008). $16 \mathrm{~S}$ rRNA gene sequence similarity was calculated using the ARB program with Jukes and Cantor correction (Jukes \& Cantor, 1969; Ludwig et al., 2004). Fluorescence in situ hybridization (FISH) was done according to the method described by Sekiguchi et al. (1998). To detect strain SMSP $^{\mathrm{T}}$ by FISH, we used probe SMSP129 (5'-TATCCCCTTCCATAGGGTAGATT-3'; E. coli positions 129151), which was designed by using the ARB program (Ludwig et al., 2004). Hybridization stringency of the probe was adjusted by changing the formamide concentration in the hybridization buffer; stringent conditions for probe SMSP129 were determined to be $35 \%(\mathrm{v} / \mathrm{v})$ formamide in the hybridization buffer. The oligonucleotide probe was labelled with $\mathrm{Cy}-3$.

Our preliminary analysis of the archaeal $16 \mathrm{~S}$ rRNA gene clone library revealed that the methanogenic granular sludge used as the inoculum contained clones belonging to group E1/E2 within the order Methanomicrobiales, accounting for $41.7 \%$ (20 of 48 clones) of the total archaeal population (Supplementary Table S1 and Fig. S1). In our previous study, we used propionate as substrate for enrichment of a methanogen belonging to group E1/E2, and we successfully cultivated and eventually isolated the methanogen Methanolinea tarda NOBI- ${ }^{\mathrm{T}}$ (Imachi et al., 2008; Sakai et al., 2007). Thus, to cultivate E1/E2 organisms thriving in the methanogenic granular sludge, we incubated the sludge anaerobically with $20 \mathrm{mM}$ propionate. Cell growth and methane production accompanied by propionate degradation occurred after 1 month of incubation. 
The culture was successively transferred into fresh medium every $30-40$ days [10\% (v/v) inoculum]. During cultivation, the partial pressure of $\mathrm{H}_{2}$ in the cultures remained less than $30 \mathrm{~Pa}$. Microscopic observation showed that, after five transfers, the propionate enrichment culture contained at least three morphologically distinct organisms: (i) blunt-ended rod-shaped, $\mathrm{F}_{420}$-autofluorescent cells, (ii) Methanosaeta-like thick rods and (iii) oval rods. These results suggested that a syntrophic association of propionate-degrading $\mathrm{H}_{2}$-producing syntrophs, hydrogenotrophic methanogens and aceticlastic methanogens carried out propionate degradation. To identify the methanogens thriving in the syntrophic propionate-degrading enrichment culture, we constructed an archaeal 16S rRNA
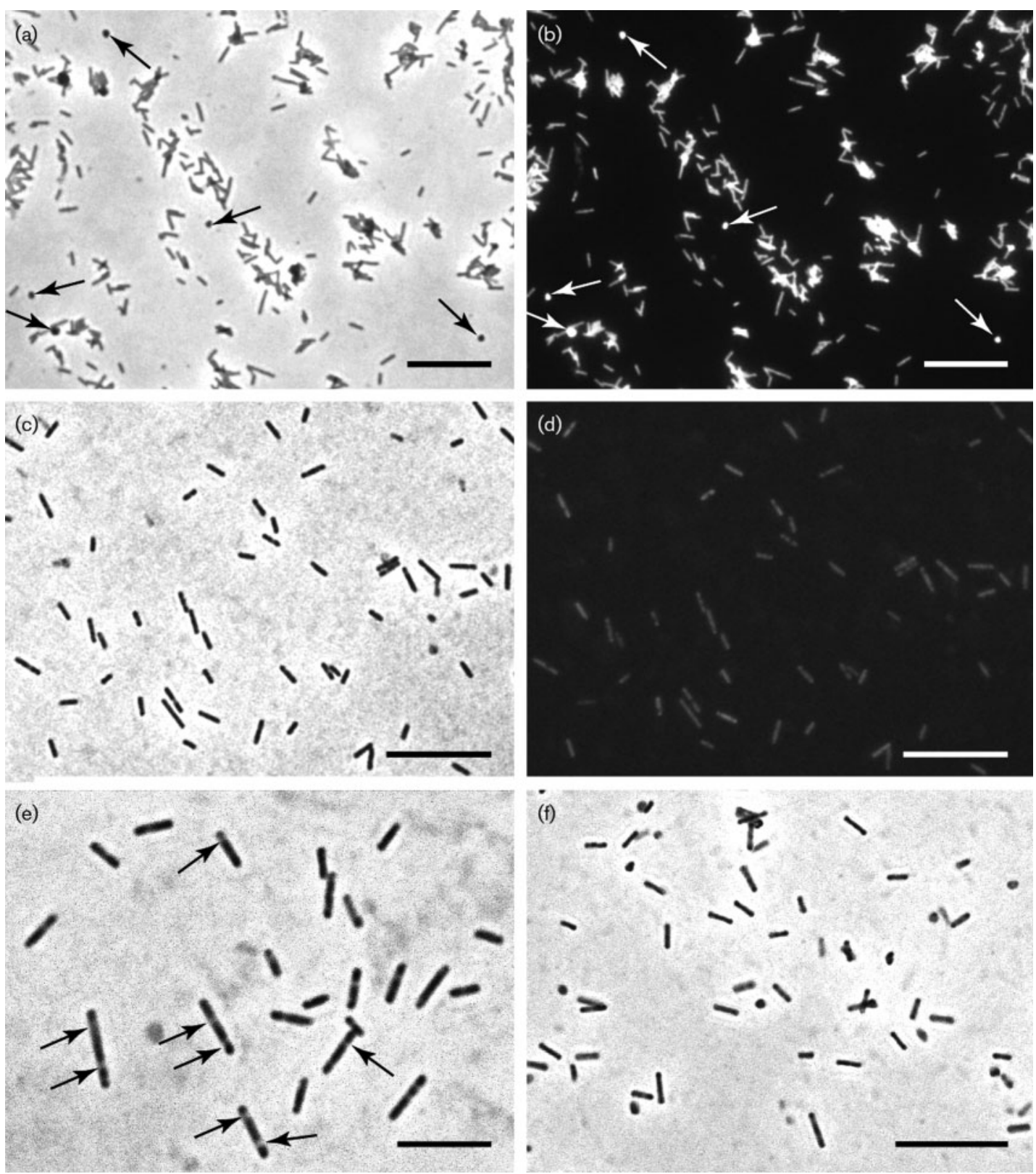

Fig. 1. Photomicrographs of strain $\mathrm{SMSP}^{\top}$ grown on formate $(40 \mathrm{mM})$ medium supplemented with acetate $(1 \mathrm{mM})$, yeast extract $(0.01 \%)$ and coenzyme M $(0.5 \mathrm{mM})$. ( $(\mathrm{a}, \mathrm{b}) \mathrm{FISH}$ of SMSP${ }^{\top}$ cells. Phase-contrast (a) and fluorescence (b) images of cells of strain $\mathrm{SMSP}^{\top}$ stained with probe SMSP129. Arrows indicate coccoid cells. (c, d) Photomicrographs of a midexponential phase culture obtained by phase-contrast (c) and fluorescence (d) microscopy indicating the presence of the methanogen-specific coenzyme $\mathrm{F}_{420}$ in identical fields. (e) Asymmetrical cell division in rod cells of strain $\mathrm{SMSP}^{\top}$; arrows indicate asymmetrical division points. ( $f$ ) Phase-contrast micrograph of a late-exponential phase culture contained rods and coccoid cells. Bars, $10 \mu \mathrm{m}$ (a-d and f) and $5 \mu \mathrm{m}(\mathrm{e})$. 
gene clone library. 16S rRNA gene clone analysis detected many archaeal sequences, which were mostly affiliated with group E1/E2 within the order Methanomicrobiales (8 out of 10 clones; phylotypes SMS-T-Pro-1 to -4 in Supplementary Table S2 and Fig. S1). We also retrieved phylotypes affiliated with group E1' within the order Methanomicrobiales (phylotype SMS-T-Pro-7 in Supplementary Fig. S1 and Table S2) (Cadillo-Quiroz et al., 2006) and with the genus Methanosaeta, containing aceticlastic methanogens (Supplementary Table S2; phylotypes SMS-T-Pro-5 and -6). To obtain the microbes belonging to the E1/E2 phylotype in pure culture from the propionate enrichment, we used a serial dilution method with both liquid and solid media supplemented with formate $(40 \mathrm{mM})$ and hydrogen (approx. $150 \mathrm{kPa}$ in the headspace), with the propionate enrichment as the inoculum. As a result, we obtained a pure culture of the methanogenic archaeon strain $\mathrm{SMSP}^{\mathrm{T}}$ in solid medium (deep-agar method) supplemented with formate. Colonies formed in deep agar after 2 months of incubation were brownish, lens-shaped and $0.1 \mathrm{~mm}$ in diameter. The purity of strain $\mathrm{SMSP}^{\mathrm{T}}$ was demonstrated by failure to grow in the following media at 37 and $55{ }^{\circ} \mathrm{C}$ : thioglycolate medium (Difco) containing approx. $150 \mathrm{kPa} \mathrm{H}_{2} / \mathrm{CO}_{2}$ (in the headspace) and $10 \mathrm{mM}$ sulfate, thioglycolate medium containing $20 \mathrm{mM}$ lactate and $10 \mathrm{mM}$ sulfate, thioglycolate medium containing $10 \mathrm{mM}$ sucrose, $10 \mathrm{mM}$ glucose, $10 \mathrm{mM}$ cellobiose and $10 \mathrm{mM}$ xylose and $\mathrm{AC}$ medium (Difco). Moreover, we also confirmed the culture purity by the failure to recover bacterial 16S rRNA gene amplifications by PCR with a universal bacterial primer pair EUB338F (Amann et al., 1990; Daims et al., 1999; Hatamoto et al., 2007)/1490R. In addition, we performed FISH with 16S rRNA-targeted oligonucleotide probe SMSP129 specific for strain SMSP ${ }^{\mathrm{T}}$, and we confirmed that all cells hybridized with the probe (Fig. 1a, b). These results of molecular surveys also indicated that the culture of strain $\mathrm{SMSP}^{\mathrm{T}}$ was axenic.
Cells of strain $\mathrm{SMSP}^{\mathrm{T}}$ were non-motile, blunt-ended, straight rods, $1.0-2.6 \mu \mathrm{m}$ long and $0.5 \mu \mathrm{m}$ wide; cells up to $7.0 \mu \mathrm{m}$ long were sometimes observed (Fig. 1c, d). Asymmetrical cell division was observed in rod-shaped cells (Fig. 1e). Coccoid cells $(0.5-1.0 \mu \mathrm{m}$ diameter) were also observed in mid- to late-exponential phase cultures (Fig. 1f). Targeting of cells of strain SMSP ${ }^{\mathrm{T}}$ by FISH probe SMSP129 demonstrated that both cell types belong to strain $\mathrm{SMSP}^{\mathrm{T}}$ (Fig. 1a, b). Cells of strain $\mathrm{SMSP}^{\mathrm{T}}$ were autofluorescent in epifluorescence microscopy when excited with light with wavelengths near $420 \mathrm{~nm}$, indicating the presence of the methanogen-specific coenzyme $\mathrm{F}_{420}$ (Fig. 1d). An SDS-resistance test revealed that cell disruption occurred at SDS concentrations $\geqslant 0.5 \%(\mathrm{w} / \mathrm{v})$.

Strain SMSP $^{\mathrm{T}}$ was strictly anaerobic, as no growth occurred under trace quantities of oxygen $\left[0.1\right.$ and $\left.0.2 \%(\mathrm{v} / \mathrm{v}) \mathrm{O}_{2}\right] . \mathrm{H}_{2}$ and formate $(40 \mathrm{mM})$ supported growth and methane production. Yeast extract and acetate were required for growth. Coenzyme $\mathrm{M}$ stimulated growth of strain $\mathrm{SMSP}^{\mathrm{T}}$ greatly; however, it was not required. The following substrates did not support growth and/or methane production: acetate $(20 \mathrm{mM})$, pyruvate, trimethylamine, dimethylamine, methylamine, cyclopentanol (all at $10 \mathrm{mM}$ ), ethanol (5 mM), methanol (20 mM), 1-propanol, 2-propanol, 1butanol and 2-butanol (all at $5 \mathrm{mM}$ ).

Growth and methanogenesis of strain $\mathrm{SMSP}^{\mathrm{T}}$ were observed between 10 and $40{ }^{\circ} \mathrm{C}$ (optimum, $30-33{ }^{\circ} \mathrm{C}$ ). The $\mathrm{pH}$ range for growth was $\mathrm{pH}$ 7.0-7.6 (optimum, $\mathrm{pH}$ 7.4). Under optimum conditions $\left(\mathrm{pH} 7.4,33{ }^{\circ} \mathrm{C}\right)$, the specific growth rate on formate medium was approx. $1.0 \mathrm{day}^{-1}$, which was calculated based on measurement of $\mathrm{OD}_{400}$. The strain could grow with $0-10 \mathrm{~g} \mathrm{NaCl} \mathrm{l}^{-1}(0-171 \mathrm{mM})$ and could tolerate rifampicin, ampicillin, penicillin, kanamycin, vancomycin and streptomycin. Tetracycline and chloramphenicol inhibited cell growth completely (each antibiotic was tested at $100 \mu \mathrm{g} \mathrm{ml}^{-1}$ ).

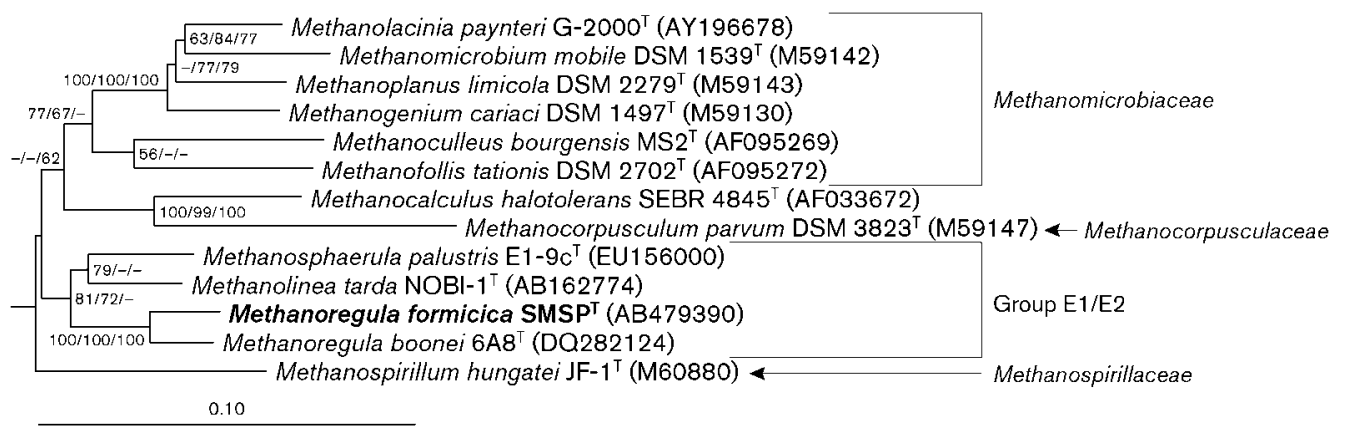

Fig. 2. Phylogenetic tree of members of the order Methanomicrobiales based on comparative analysis of 16S rRNA gene sequences, showing the placement of strain $\mathrm{SMSP}^{\top}$. The tree was calculated based on a distance-matrix analysis of $16 \mathrm{~S}$ rRNA gene sequences (neighbour-joining tree). Three 16S rRNA gene sequences from members of the class Thermoplasmata [Picrophilus oshimae KAW2/2 ${ }^{\top}$ (GenBank accession no. X84901), clone WCHD3-02 (AF050616) and clone pMC2A24 (AB019736)] were used to root the tree (not shown). Bootstrap percentages were obtained from the neighbour-joining/ maximum-parsimony/maximum-likelihood methods based on 1000 replicates;,$-<50 \%$. Accession numbers are shown in parentheses. Bar, 0.1 changes per nucleotide sequence position. 


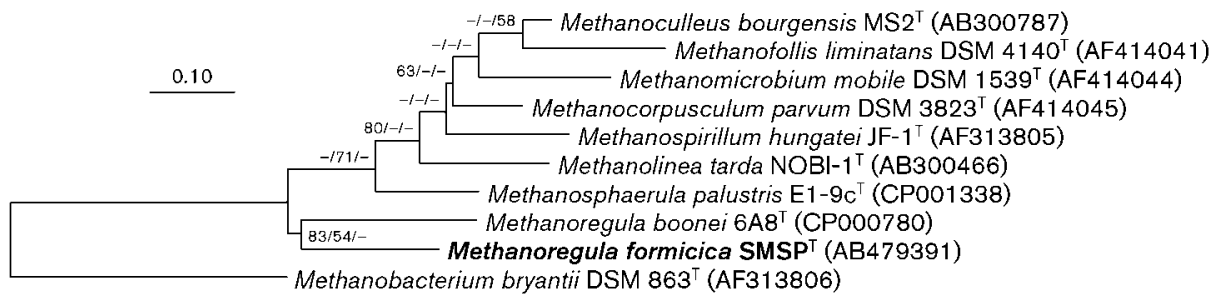

Fig. 3. Phylogenetic tree based on deduced McrA amino acid sequences, indicating the relationship of strain SMSP with related methanogenic archaea. The tree was constructed based on a distance matrix (256 amino acid positions; PAM distance correction) by the neighbour-joining method. The sequence of Methanobacterium bryantii DSM $863^{\top}$ was used as the outgroup. Accession numbers are shown in parentheses. Bootstrap percentages were obtained from the neighbourjoining/maximum-parsimony/maximum-likelihood methods based on 1000 replicates;,$-<50 \%$. Bar, $10 \%$ sequence divergence.

The DNA G + C content of strain $\mathrm{SMSP}^{\mathrm{T}}$ was $56.2 \mathrm{~mol} \%$. Comparative $16 \mathrm{~S}$ rRNA gene sequence analysis using $1397 \mathrm{bp}$ of the 16S rRNA gene sequence of strain SMSP showed that strain $\mathrm{SMSP}^{\mathrm{T}}$ was affiliated with group E1/E2 with the order Methanomicrobiales (Fig. 2). The 16S rRNA gene sequence of strain $\mathrm{SMSP}^{\mathrm{T}}$ was not identical to any clonal sequence retrieved from the propionate enrichment culture or the original methanogenic sludge, although phylotype SMS-T-Pro-4 detected from the propionate enrichment was closely related to strain $\mathrm{SMSP}^{\mathrm{T}}$ (97.0\% $16 \mathrm{~S}$ rRNA gene sequence identity; Supplementary Fig. S1). The discrepancy between the sequence of SMSP ${ }^{\mathrm{T}}$ and the clonal sequences suggests that strain $\mathrm{SMSP}^{\mathrm{T}}$ was a minor archaeal component in the original methanogenic sludge and the propionate enrichment, and thus the sequence of strain SMSP $^{\mathrm{T}}$ could not be retrieved from the archaeal clone libraries. The closest cultured relative of strain $\mathrm{SMSP}^{\mathrm{T}}$ was Methanoregula boonei $6 \mathrm{~A} 8^{\mathrm{T}}$ (96.3\% sequence identity). In addition to the $16 \mathrm{~S}$ rRNA gene sequence-based analysis, we also determined the partial sequence of the $m c r A$ gene of strain $\mathrm{SMSP}^{\mathrm{T}}(722 \mathrm{bp})$ and constructed a phylogenetic tree based on deduced amino acid sequences of the mcrA gene

Table 1. Differential characteristics between strain $S M S P^{\top}$ and other members of group E1/E2 within the order Methanomicrobiales

Strains: 1, strain $\mathrm{SMSP}^{\mathrm{T}}$ (data from this study); 2, Methanoregula boonei 6A8 ${ }^{\mathrm{T}}$ (data from Bräuer et al., 2006a, 2011); 3, Methanosphaerula palustris E1-9c ${ }^{\mathrm{T}}$ (Cadillo-Quiroz et al., 2008, 2009); 4, Methanolinea tarda NOBI-1 ${ }^{\mathrm{T}}$ (Imachi et al., 2008). ND, No data available.

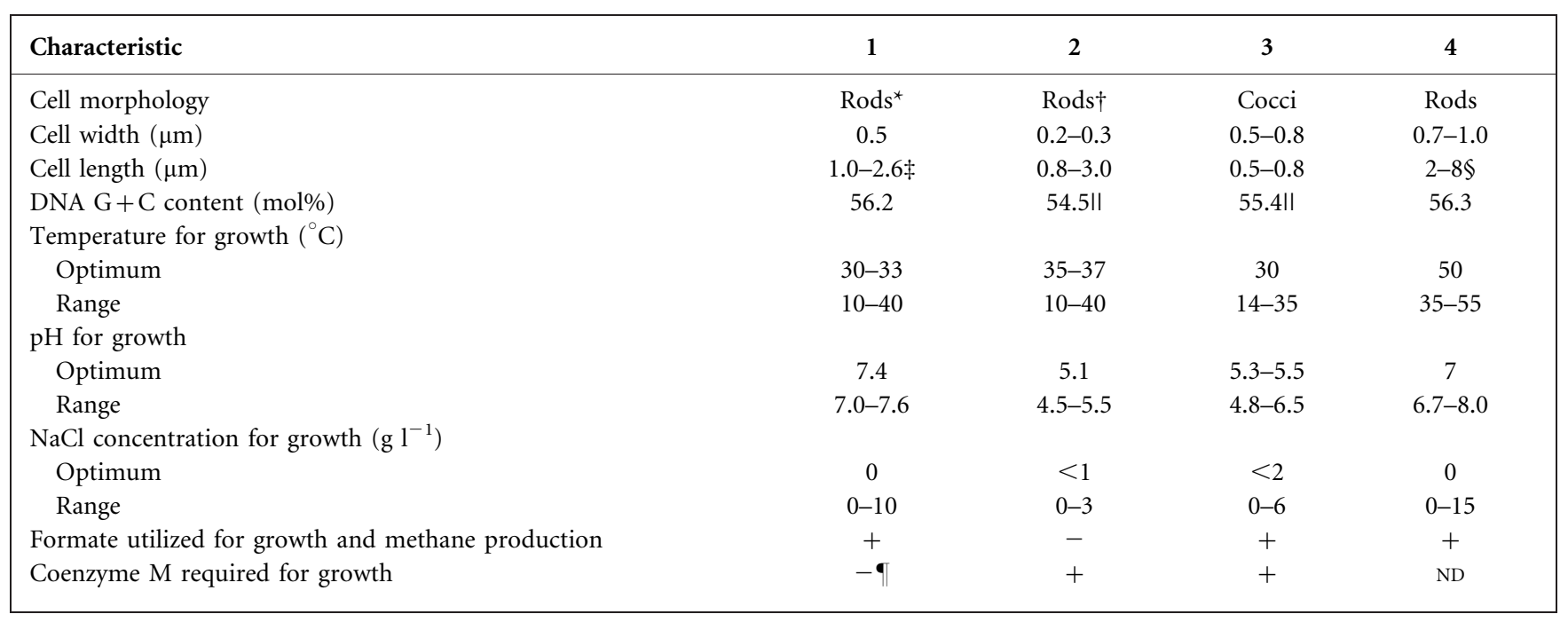

${ }^{\star}$ Irregular coccoid cells, $0.5-1.0 \mu \mathrm{m}$ in diameter, observed in mid- to late-exponential phase.

$\dagger$ Cells sometimes become spherical, diameter $0.3-0.8 \mu \mathrm{m}$.

$\ddagger$ Cells up to $7 \mu \mathrm{m}$ long sometimes observed.

$\S$ Cells often form multicellular filaments longer than $8 \mu \mathrm{m}$ in syntrophic propionate-degrading enrichment culture.

IIDNA G + C content determined from full genome sequence (http://www.ncbi.nlm.nih.gov/genomes/lproks.cgi).

Growth is greatly stimulated. 
(Fig. 3). The McrA tree also supported the conclusion that strain $\mathrm{SMSP}^{\mathrm{T}}$ was a member of the order Methanomicrobiales, and the closest relative on the basis of deduced McrA amino acid sequences was also Methanoregula boonei $6 \mathrm{~A} 8^{\mathrm{T}}$ (85.4\% sequence identity).

The phenotypic and genetic data obtained in this study showed that strain $\mathrm{SMSP}^{\mathrm{T}}$ and Methanoregula boonei $6 \mathrm{~A} 8^{\mathrm{T}}$ have very similar features. The $16 \mathrm{~S}$ rRNA gene sequence similarity of $96.3 \%$ is in the range of species-level differences (Stackebrandt \& Goebel, 1994; Keswani \& Whitman, 2001) and is similar to species-level differences among described species in genera belonging to the order Methanomicrobiales, e.g. Methanoculleus (96.3-96.9\%) and Methanofollis (95.2-95.6\%). Thus, strain $\mathrm{SMSP}^{\mathrm{T}}$ and Methanoregula boonei $6 \mathrm{~A} 8^{\mathrm{T}}$ should be members of the same genus. In addition to the 16S rRNA gene sequence similarity, their cell morphologies are similar, i.e. both organisms have blunt-ended, straight rod-shaped and coccoid-shaped cells (Table 1). In addition, their most striking feature is their asymmetrical cell division (Bräuer et al., 2006a) (Fig. 1e). Moreover, their optimum growth temperatures were similar (strain $\mathrm{SMSP}^{\mathrm{T}}, 30-33^{\circ} \mathrm{C}$; Methanoregula boonei $\left.6 \mathrm{~A} 88^{\mathrm{T}}, 35-37^{\circ} \mathrm{C}\right)$ and their growth temperature ranges were the same $\left(10-40{ }^{\circ} \mathrm{C}\right)$. However, the $\mathrm{pH}$ ranges for growth differ markedly; the optimum $\mathrm{pH}$ for strain $\mathrm{SMSP}^{\mathrm{T}}$ is $\mathrm{pH}$ 7.4, whereas that for Methanoregula boonei $6 \mathrm{~A}^{\mathrm{T}}$ is $\mathrm{pH}$ 5.1. Additionally, substrate usage was different, in that strain $\mathrm{SMSP}^{\mathrm{T}}$ can utilize formate whereas Methanoregula boonei $6 \mathrm{~A} 8^{\mathrm{T}}$ cannot. Based on these phenotypic and phylogenetic properties, we assign strain $\mathrm{SMSP}^{\mathrm{T}}$ to a novel species of the genus Methanoregula, for which we propose the name Methanoregula formicica sp. nov.

\section{Description of Methanoregula formicica sp. nov.}

Methanoregula formicica (for.mi'ci.ca. N.L. n. acidum formicum formic acid; L. fem. suff. -ica suffix used with the sense of pertaining to; N.L. fem. adj. formicica pertaining to formic acid, referring to the ability of the type strain to utilize formate).

Strictly anaerobic. Cells are non-motile and rod-shaped, $1.0-7 \mu \mathrm{m}$ long and $0.5 \mu \mathrm{m}$ wide. In mid- to lateexponential phase cultures, coccoid cells are observed $(0.5-1.0 \mu \mathrm{m}$ diameter). Asymmetrical cell division is observed. Hydrogen and formate are used for growth and methane production. Yeast extract and acetate are required for growth. Coenzyme M stimulates growth greatly. The temperature range for growth is $10-40{ }^{\circ} \mathrm{C}$ (optimum, 30 $33{ }^{\circ} \mathrm{C}$ ). The $\mathrm{pH}$ range for growth is 7.0-7.6 (optimum, $\mathrm{pH}$ 7.4). Growth occurs in the presence of $0-10 \mathrm{~g} \mathrm{NaCl}$ $1^{-1}$, but does not occur in the presence of $20 \mathrm{~g} \mathrm{NaCl}^{-1}$. The $\mathrm{G}+\mathrm{C}$ content of the DNA of the type strain is $56.2 \mathrm{~mol} \%$.

The type strain, SMSP ${ }^{\mathrm{T}}\left(=\mathrm{NBRC} 105244^{\mathrm{T}}=\mathrm{DSM} 22288^{\mathrm{T}}\right)$, was isolated from a mesophilic, granular sludge in a UASB reactor used to treat a beer brewery effluent.

\section{Acknowledgements}

We thank Hideki Inaba at Sumitomo Heavy Industries, Ltd, for his assistance with the sampling of the methanogenic sludge and Dr Eiji Tasumi and Ken Aoi at JAMSTEC for their technical assistance. We also thank Drs Stephen H. Zinder, Hinsby Cadillo-Quiroz and Suzanna L. Bräuer for valuable discussion, critical reading of the manuscript and providing information on Methanoregula boonei and Methanosphaerula palustris. This study was supported partly by grants from the Ministry of Education, Culture, Sports, Science and Technology, Japan, the Japan Society for the Promotion of Science and the Institute for Fermentation, Osaka.

\section{References}

Amann, R. I., Binder, B. J., Olson, R. J., Chisholm, S. W., Devereux, R. \& Stahl, D. A. (1990). Combination of $16 \mathrm{~S}$ rRNA-targeted oligonucleotide probes with flow cytometry for analyzing mixed microbial populations. Appl Environ Microbiol 56, 1919-1925.

Bräuer, S. L., Cadillo-Quiroz, H., Yashiro, E., Yavitt, J. B. \& Zinder, S. H. (2006a). Isolation of a novel acidiphilic methanogen from an acidic peat bog. Nature 442, 192-194.

Bräuer, S. L., Yashiro, E., Ueno, N. G., Yavitt, J. B. \& Zinder, S. H. (2006b). Characterization of acid-tolerant $\mathrm{H}_{2} / \mathrm{CO}_{2}$-utilizing methanogenic enrichment cultures from an acidic peat bog in New York State. FEMS Microbiol Ecol 57, 206-216.

Bräuer, S. L., Cadillo-Quiroz, H., Ward, R. J., Yavitt, J. B. \& Zinder, S. H. (2011). Methanoregula boonei gen. nov., sp. nov., an acidiphilic methanogen isolated from an acidic peat bog. Int J Syst Evol Microbiol 61, 45-52.

Cadillo-Quiroz, H., Bräuer, S., Yashiro, E., Sun, C., Yavitt, J. \& Zinder, S. (2006). Vertical profiles of methanogenesis and methanogens in two contrasting acidic peatlands in central New York State, USA. Environ Microbiol 8, 1428-1440.

Cadillo-Quiroz, H., Yashiro, E., Yavitt, J. B. \& Zinder, S. H. (2008). Characterization of the archaeal community in a minerotrophic fen and terminal restriction fragment length polymorphism-directed isolation of a novel hydrogenotrophic methanogen. Appl Environ Microbiol 74, 2059-2068.

Cadillo-Quiroz, H., Yavitt, J. B. \& Zinder, S. H. (2009). Methanosphaerula palustris gen. nov., sp. nov., a hydrogenotrophic methanogen isolated from a minerotrophic fen peatland. Int J Syst Evol Microbiol 59, 928-935.

Chan, O. C., Wolf, M., Hepperle, D. \& Casper, P. (2002). Methanogenic archaeal community in the sediment of an artificially partitioned acidic bog lake. FEMS Microbiol Ecol 42, 119-129.

Chan, O. C., Claus, P., Casper, P., Ulrich, A., Lueders, T. \& Conrad, R. (2005). Vertical distribution of structure and function of the methanogenic archaeal community in Lake Dagow sediment. Environ Microbiol 7, 1139-1149.

Chen, C.-L., Macarie, H., Ramirez, I., Olmos, A., Ong, S. L., Monroy, O. \& Liu, W.-T. (2004). Microbial community structure in a thermophilic anaerobic hybrid reactor degrading terephthalate. Microbiology 150, 3429-3440.

Chen, C.-L., Wu, J.-H., Tseng, I.-C., Liang, T.-M. \& Liu, W.-T. (2009). Characterization of active microbes in a full-scale anaerobic fluidized bed reactor treating phenolic wastewater. Microbes Environ 24, 144153.

Daims, H., Brühl, A., Amann, R., Schleifer, K. H. \& Wagner, M. (1999). The domain-specific probe EUB338 is insufficient for the detection of all bacteria: development and evaluation of a more comprehensive probe set. Syst Appl Microbiol 22, 434-444. 
DeLong, E. F. (1992). Archaea in coastal marine environments. Proc Natl Acad Sci U S A 89, 5685-5689.

Dojka, M. A., Hugenholtz, P., Haack, S. K. \& Pace, N. R. (1998). Microbial diversity in a hydrocarbon- and chlorinated-solventcontaminated aquifer undergoing intrinsic bioremediation. Appl Environ Microbiol 64, 3869-3877.

Ficker, M., Krastel, K., Orlicky, S. \& Edwards, E. (1999). Molecular characterization of a toluene-degrading methanogenic consortium. Appl Environ Microbiol 65, 5576-5585.

Galand, P. E., Saarnio, S., Fritze, H. \& Yrjälä, K. (2002). Depth related diversity of methanogen Archaea in Finnish oligotrophic fen. FEMS Microbiol Ecol 42, 441-449.

Großkopf, R., Janssen, P. H. \& Liesack, W. (1998). Diversity and structure of the methanogenic community in anoxic rice paddy soil microcosms as examined by cultivation and direct 16S RNA gene sequence retrieval. Appl Environ Microbiol 64, 960-969.

Hales, B. A., Edwards, C., Ritchie, D. A., Hall, G., Pickup, R. W. \& Saunders, J. R. (1996). Isolation and identification of methanogenspecific DNA from blanket bog peat by PCR amplification and sequence analysis. Appl Environ Microbiol 62, 668-675.

Hatamoto, M., Imachi, H., Ohashi, A. \& Harada, H. (2007). Identification and cultivation of anaerobic, syntrophic long-chain fatty acid-degrading microbes from mesophilic and thermophilic methanogenic sludges. Appl Environ Microbiol 73, 1332-1340.

Imachi, H., Sekiguchi, Y., Kamagata, Y., Loy, A., Qiu, Y.-L., Hugenholtz, P., Kimura, N., Wagner, M., Ohashi, A. \& Harada, H. (2006). Non-sulfate-reducing, syntrophic bacteria affiliated with Desulfotomaculum cluster I are widely distributed in methanogenic environments. Appl Environ Microbiol 72, 2080-2091.

Imachi, H., Sakai, S., Sekiguchi, Y., Hanada, S., Kamagata, Y., Ohashi, A. \& Harada, H. (2008). Methanolinea tarda gen. nov., sp. nov., a methane-producing archaeon isolated from a methanogenic digester sludge. Int J Syst Evol Microbiol 58, 294-301.

Imachi, H., Sakai, S., Nagai, H., Yamaguchi, T. \& Takai, K. (2009). Methanofollis ethanolicus sp. nov., an ethanol-utilizing methanogen isolated from a lotus field. Int J Syst Evol Microbiol 59, 800-805.

Jukes, T. H. \& Cantor, C. R. (1969). Evolution of protein molecules. In Mammalian Protein Metabolism, vol. 3, pp. 21-132. Edited by $\mathrm{H}$. N. Munro. New York: Academic Press.

Jurgens, G., Glöckner, F., Amann, R., Saano, A., Montonen, L., Likolammi, M. \& Münster, U. (2000). Identification of novel archaea in bacterioplankton of a boreal forest lake by phylogenetic analysis and fluorescent in situ hybridization. FEMS Microbiol Ecol 34, 45-56.

Keswani, J. \& Whitman, W. B. (2001). Relationship of $16 \mathrm{~S}$ rRNA sequence similarity to DNA hybridization in prokaryotes. Int J Syst Evol Microbiol 51, 667-678.

Ludwig, W., Strunk, O., Westram, R., Richter, L., Meier, H., Yadhukumar, Buchner, A., Lai, T., Steppi, S. \& other authors (2004). ARB: a software environment for sequence data. Nucleic Acids Res 32, 1363-1371.
Lueders, T. \& Friedrich, M. (2000). Archaeal population dynamics during sequential reduction processes in rice field soil. Appl Environ Microbiol 66, 2732-2742.

Macbeth, T. W., Cummings, D. E., Spring, S., Petzke, L. M. \& Sorenson, K. S. (2004). Molecular characterization of a dechlorinating community resulting from in situ biostimulation in a trichloroethenecontaminated deep, fractured basalt aquifer and comparison to a derivative laboratory culture. Appl Environ Microbiol 70, 7329-7341.

Nakagawa, S., Takai, K., Horikoshi, K. \& Sako, Y. (2003). Persephonella hydrogeniphila sp. nov., a novel thermophilic, hydrogen-oxidizing bacterium from a deep-sea hydrothermal vent chimney. Int J Syst Evol Microbiol 53, 863-869.

Narihiro, T., Terada, T., Ohashi, A., Wu, J.-H., Liu, W.-T., Araki, N., Kamagata, Y., Nakamura, K. \& Sekiguchi, Y. (2009). Quantitative detection of culturable methanogenic archaea abundance in anaerobic treatment systems using the sequence-specific rRNA cleavage method. ISME J 3, 522-535.

Nüsslein, B., Chin, K.-J., Eckert, W. \& Conrad, R. (2001). Evidence for anaerobic syntrophic acetate oxidation during methane production in the profundal sediment of subtropical Lake Kinneret (Israel). Environ Microbiol 3, 460-470.

Purdy, K. J., Munson, M. A., Nedwell, D. B. \& Embley, T. M. (2002). Comparison of the molecular diversity of the methanogenic community at the brackish and marine ends of a UK estuary. FEMS Microbiol Ecol 39, 17-21.

Sakai, S., Imachi, H., Sekiguchi, Y., Ohashi, A., Harada, H. \& Kamagata, Y. (2007). Isolation of key methanogens for global methane emission from rice paddy fields: a novel isolate affiliated with the clone cluster rice cluster I. Appl Environ Microbiol 73, 4326-4331.

Sekiguchi, Y., Kamagata, Y., Syutsubo, K., Ohashi, A., Harada, H. \& Nakamura, K. (1998). Phylogenetic diversity of mesophilic and thermophilic granular sludges determined by $16 \mathrm{~S}$ rRNA gene analysis. Microbiology 144, 2655-2665.

Stackebrandt, E. \& Goebel, B. M. (1994). Taxonomic note: a place for DNA-DNA reassociation and $16 \mathrm{~S}$ rRNA sequence analysis in the present species definition in bacteriology. Int J Syst Bacteriol 44, 846849.

van Hoek, A. H. A. M., van Alen, T. A., Sprakel, V. S. I., Leunissen, J. A. M., Brigge, T., Vogels, G. D. \& Hackstein, J. H. P. (2000). Multiple acquisition of methanogenic archaeal symbionts by anaerobic ciliates. Mol Biol Evol 17, 251-258.

Watanabe, K., Kodama, Y., Hamamura, N. \& Kaku, N. (2002). Diversity, abundance, and activity of archaeal populations in oil-contaminated groundwater accumulated at the bottom of an underground crude oil storage cavity. Appl Environ Microbiol 68, 3899-3907.

Weisburg, W. G., Barns, S. M., Pelletier, D. A. \& Lane, D. J. (1991). $16 \mathrm{~S}$ ribosomal DNA amplification for phylogenetic study. J Bacteriol 173, 697-703.

Wu, X. L., Friedrich, M. W. \& Conrad, R. (2006). Diversity and ubiquity of thermophilic methanogenic archaea in temperate anoxic soils. Environ Microbiol 8, 394-404. 